\title{
Improving Small Business Performance: The Role of Entrepreneurial Intensity and Innovation*
}

\author{
Sumiati SUMIATI ${ }^{1}$
}

Received: July 18, 2020 Revised: August 23, 2020 Accepted: September 03, 2020

\begin{abstract}
The Small and Medium Enterprise is currently getting more attention from the Indonesian government as the contribution of this sector to the regional and national income has increased. Though the government is providing a lot of attention as well as facilities to the small businesses in the manufacturing sector, they face intense competition. Thus, the small enterprises need to ensure that they achieve good business performance. This research aims to investigate the role of entrepreneurial intensity and innovation in improving the performance of small businesses in Indonesia. For this purpose, one hundred and eighty-six small business owners participated in the survey. The data was analyzed using Structural Equation Modelling. The hypothesis results show that entrepreneurial intensity and innovation have a proven role in business performance of small enterprises. Entrepreneurial intensity in particular, significantly impacts innovation and exploration. And innovation is crucial for business performance. The results imply that to increase business performance, the owner and the manager also need to raise their entrepreneurial spirit, as it can enhance their willingness to explore and use their business experience to do more innovation activities. The more innovation is done by the company; the business performance is more likely to improve.
\end{abstract}

Keywords: Entrepreneurial Intensity, Exploitative Innovation, Explorative Innovation, SME Performance

JEL Classification Code: M10, M13, O30

\section{Introduction}

The manufacturing industry is currently getting more attention from the Indonesian government as the contribution of the business units in this sector to the national and regional income has increased. The business units in the manufacturing sector are considered to be capable of creating jobs in addition to increasing the Gross Regional Domestic

\footnotetext{
*Acknowledgements:

This research paper in this publication is supported by the Directorate of Research and Community Service, Directorate General of Research and Technology Development, Ministry of Research, Technology and Higher Education Republic of Indonesia.

${ }^{1}$ First Author and Corresponding Author. Management Department, Faculty of Economics and Business, University of Brawijaya, Indonesia [Postal Address: JI. MT, Haryono 165, Malang, Jawa Timur, 65142, Indonesia] Email: sumiati@ub.ac.id
}

() Copyright: The Author(s)

This is an Open Access article distributed under the terms of the Creative Commons Attribution Non-Commercial License (https://creativecommons.org/licenses/by-nc/4.0/) which permits unrestricted non-commercial use, distribution, and reproduction in any medium, provided the original work is properly cited.
Product (GRDP). It is also helpful in improving the welfare of the local community.

Malang City is one of the regions where the business units of the manufacturing sector are very well developed. In 2016, the number of business units from all industrial sub-sectors was only 141 units while in 2017 , the number of business units in the industrial sector increased rapidly to 2,611 . The increase in the number of business units was followed by an increase in the GRDP generated from the industrial business sector. Although the contribution of the processing industry to GRDP is quite high in general, there has been a decline in its contribution to the GRDP from 28.92\% in 2016 to $25.19 \%$ in 2017 (Central Statistics Agency, 2018). The decline in the contribution shows that there is a need for an equal distribution of the growth of the number of business units in other industrial sub-sectors. The aim is to maintain the stability of contributions to GDP while maintaining positive competition between the business units operating in Malang City.

Business performance is a reflection of organizational success. A business organization that can maintain and increase its performance is more likely to have a positive 
growth rate and they tend to win over the competition in the industry. The better their business performance is, the more successful the business will be. Thus, there is a need to explore the possible antecedents of business performance.

Resource Advantage (R-A) Theory (Hunt \& Morgan, 1996) suggested that comparative advantage owned by a business organization will improve its competitive advantage, which has a lasting effect on its business performance. However, published studies have demonstrated the role of entrepreneurial intensity as a comparative organizational advantage on business performance, especially in the context of Indonesian small businesses in the manufacturing sector. For this study, entrepreneurial intensity is considered as an important factor which gives a comparative advantage to small businesses, it is an important resource in creating a competitive advantage for them. Hence, this study will determine the relationship between entrepreneurial intensity and small business performance.

Apart from the entrepreneurial intensity, innovation has been recognized widely as the antecedent of business performance. Jansen, Van den Bosch, and Volberda (2005) suggested that innovation is divided into exploratory and exploitative innovation. Exploratory innovation is about innovation that explores resources from the outside organization while the exploitative innovation tries to maximize its internal resources to do innovation. In the domain of small and medium enterprises (SMEs), previous studies have found the essential role of innovation in enhancing business performance. The study of Lestari, Leon, Widyastuti, Brabo, and Putra (2020) suggested that innovation has a positive significant effect on Indonesia's SME's performance. Similar to this study, Hoang and Ngoc (2019) suggested that Vietnam's electronic commerce industry performance was affected by innovation. While these studies have shown the essential roles of innovation in enhancing business performance, published studies have explored the effects of both exploitative and exploratory innovation in Indonesian SMEs especially in the manufacturing sector. As innovation mostly results from the entrepreneurial mindset, it is predicted that both exploratory and exploitative innovation will also have an equal effect on entrepreneurial intensity on small business performance.

This study aims to investigate the effect of intensity on small business performance in the context of the Indonesian manufacturing industry and to scrutinize the mediating effect of innovation on the relationship between entrepreneurial intensity and small business performance.

Upon the completion of this study, both theoretical and practical contributions have been provided. From a theoretical standpoint, this study will explain the effect of entrepreneurial intensity as a comparative advantage on business performance as well as showing the mediating role of innovation. As a practical contribution, this study will provide guidelines for business practitioners to enhance their performance.

\section{Literature Review}

\subsection{Entrepreneurial Intensity and Small Business Performance}

Resource-Advantage Theory (Hunt \& Morgan, 2005) suggested that the comparative advantage owned by the business organizations is an essential resource in creating a competitive advantage, and the competitive advantage is useful for an organization to increase its business performance. Based on this theory, to remain ahead in the competition, every business must have a distinct resource that cannot be copied easily by other organizations. Entrepreneurial intensity, which is the level of entrepreneurial focus and commitment in leading business innovations, is an irreplaceable resource in creating competitive advantage (Jianwen 2005).

Business performance is a result that is shown through a comparison between targets and achievements by a business unit within a certain period of time. Semrau et al. (2016) explains the measurement of a company's performance can be measured through two dimensions, namely the financial dimension and non-financial dimensions. Financial measurements can be done through comparison of changes in value in financial statements issued by companies. Non-financial measurements can be done through stakeholder satisfaction and organizational structure growth.

Measuring company performance is subjective, meaning that performance measurement is very dependent on the subject that performs and the measurement tools used. Fairoz et al. (2010) form performance measurements by combining financial and non-financial components. The financial component includes profit growth, while the non-financial component is measured through sales, employee growth, market share, and business owner satisfaction (Fairoz et al., 2010; Shehu \& Mahmood, 2014).

While theoretically, it has been recognized as an important resource to win the business competition, to date, just a few studies have discussed the role of the entrepreneurial intensity of the business performance. The study by Morris and Sexton (1996) and Zhang et al. (2016) showed that entrepreneurial intensity had a significant positive effect on business performance. Similar to this study, Urban and Sefalafala (2015) suggested that entrepreneurial intensity significantly 
affected SMEs' performance and internationalization in South Africa. The effect of entrepreneurial intensity on firm performance was also indicated in the survey conducted on the Russian women entrepreneurs (Lakovleva \& Kickul, 2011). Nguyen, Pham, Dao, Ngo, and Le (2020) contended that individual innovativeness as a part of entrepreneurial intensity, is the determinant of business innovation. Thus, based on previous studies, it is proposed:

H1: Entrepreneurial Intensity has a significant positive effect on business performance

\subsection{Mediating Role of Innovation}

Market conditions and level of business competition that is increasingly erratic and constantly changing demands innovation to gain a competitive advantage. Higgins (1995) states that the key to success in terms of competitive advantage is innovation. Innovation can be differentiated into product innovation (Bakar \& Ahmad, 2010; Zhang \& Duan, 2010), process innovation, and market innovation (Medina \& Rufin, 2009; Murat \& Baki, 2011). Hogan and Coote (2014) defined innovation as one of the functions that companies need to make to create a new dimension of performance. Innovation can be triggered by changes in the company's internal and external environment, which will then provide an opportunity for the company to create a new procedure or systematic process to improve the overall performance of the company.

Innovation can be either exploratory or exploitative. Exploitation is defined as the use and refinement of knowledge and skills in developing an existing product
(Cingöz \& Akdoğan, 2013). Thus, it can be said that exploitation is an activity carried out in response to current environmental conditions by adapting existing technology to meet the needs of existing customers as well. Whereas exploration refers more to the search for new knowledge and skills in developing new products (Cingöz \& Akdoğan, 2013). Therefore, it can be concluded that exploration includes search, experimentation, risk taking, flexibility and discovery. The methods of marketing and developing new technologies are very important to do exploratory innovation. Both these innovations, exploitative and explorative, require different organizational structures and processes.

Jansen, Van Den Bosch, and Volberda (2006) suggested that two types of innovations which will enhance business performance are exploratory innovation and exploitative innovation. Exploratory innovation is by business organizations by exploring resources from outside the organization. Exploitative innovation is achieved by exploiting resources owned by the organization. Previous studies have found that both these innovations have an effect on the business performance (Jansen et al., 2005, Li, Zhou, \& Si, 2010; Mueller, Rosenbusch, \& Bausch, 2013).

Innovation cannot be separated from entrepreneurship. Wiklund and Shepherd (2005) argued that innovation is an important dimension of entrepreneurship. The relationship between entrepreneurial intensity and innovation might be explained by R-A Theory (Hunt \& Morgan, 2005). According to this theory, the comparative advantage goes to the firm which creates a competitive advantage. Hence, as a unique resource, the entrepreneurial intensity will create innovation as the competitive advantage for small businesses.

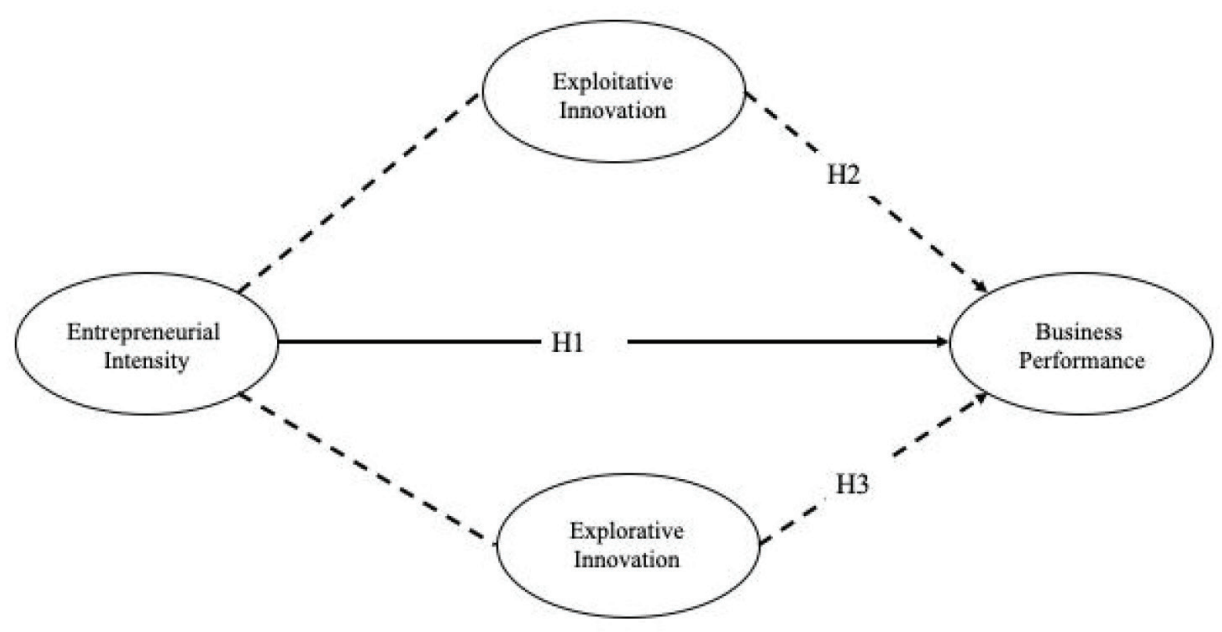

Figure 1: Conceptual Model 
As innovations, both exploratory and innovative innovations are determinant of business performance, and it is the result of entrepreneurial intensity that there is a possibility that it will mediate the effect of entrepreneurial intensity on the performance of small businesses. Based on the explanation, this study suggested:

H2: Exploratory innovation mediates the effect of entrepreneurial intensity on small business performance

H3: Exploitative innovation mediates the effect of entrepreneurial intensity on small business performance.

\section{Research Methods and Materials}

\subsection{Population and Sample}

This research is explanatory research that aims to see the relationship between selected variables. The population of this research are all consumers of fashion brands in small and medium scale in the city of Malang. This study uses a non-probability sampling technique with a purposive sampling method using several criteria. The criteria used for sampling in this study are as follows:

(1) The businesses surveyed have a legal entity of at least an individual company; (2) in the last five years, they have operated for a minimum of three consecutive years.

The collected data was analysed using Structural Equation Modelling using AMOS software. Before the hypothesis test is carried out, a Confirmatory Factor Analysis (CFA) is performed to see the suitability of the model formed. Evaluation of model through the CFA test was carried out using several indices, including absolute fit indices (chi-square, RMSEA, GFI and SRMR), incremental fit indices (CFI and NFI), and parsimonious fit index (PGFI). Some indexes can be used to assess the fitness of the proposed model. Table 1 lists the model fit indices and the recommended thresholds.

\subsection{Measures}

The questionnaires used were divided into two sections. The first section measured the demographical data of respondents, while the second section measured the constructs used. The measures used in this study were adapted from several literatures. Business performance was adapted from Lee et al. (2015), both exploratory and exploitative innovations were adapted from Li et al. (2010) and Jansen et al. (2005), and entrepreneurial intensity was adapted from Jianwen (2005). Five points Likert scale anchored from strongly disagree (1) to strongly agree (5) was used in this study.
Table 1: Goodness of Fit Index

\begin{tabular}{|c|c|}
\hline Model Fit Indices & Recommended Thresholds \\
\hline \multicolumn{2}{|c|}{ Parsimonious Fit Indices } \\
\hline$x^{2} / d f$ & $\leq 3$ \\
\hline PGFI & $\geq 0.6$ \\
\hline \multicolumn{2}{|l|}{ Absolute Fit Indices } \\
\hline$x^{2}$ & $\Delta x^{2}>x^{2}$ table \\
\hline GFI & $\geq 0.9$ \\
\hline RSMEA & $\leq 0.06$ \\
\hline SRMR & $\leq 0.5$ \\
\hline \multicolumn{2}{|c|}{ Incremental Fit Indices } \\
\hline $\mathrm{NFI}$ & $\geq 0.9$ \\
\hline $\mathrm{CFI}$ & $\geq 0.9$ \\
\hline
\end{tabular}

\subsection{Data Analysis}

For this study, two steps Covariance based Structural Equation Model (CBSEM) was employed to analyze the data, and the mediating effect was tested through Sobel's test. The first step is to analyze the measurements used. The evaluations included evaluating convergent validity, discriminant validity and the union dimension of the construct. The second step is to evaluate the structural model. Structural model analysis is done by looking at the value of the total determination coefficient and goodness of fit model. The third step is testing the hypothesis of both direct and indirect effects. Indirect effects are tested using the sobel test. For testing hypotheses, alpha is determined at the 5\% level with $\mathrm{t}=1,960$ (Hair, Anderson, \& Tatham, 2010).

\section{Results}

\subsection{The Demography Characteristics of Respondents}

Two hundred questionnaires were distributed to managers and micro and small business owners which resulted in a response rate of $93 \%$ or 186 questionnaires worth using. With a sample of 186 respondents with a total of 110 men and 76 women. The majority of respondents (67 respondents) in this study were aged between 46 to 55,12 respondents were aged between 18 to 25,23 respondents were aged between 26 to 35,48 respondents were aged between 36 to 45, and 36 respondents were aged over 55 . Educational background of the respondents also varied. The education level of respondents was dominated by diploma graduates with as many as 88 respondents, then followed by high school graduates which had as many as 58 respondents, undergraduate graduates had as many as 19 respondents and 21 respondents had masters degrees. The length of business of each MSME also varied, with the largest average length of business that is 3-5 years 
(79 respondents), 45 respondents had a business length of 6-10 years, 27 respondents had a business length of 11-15, 34 respondents had a business length of more than 15 years, and 2 respondents did not specify their business length. Table 2 summarizes the demography of respondents.

\subsection{Confirmatory Factor Analysis (CFA)}

The initial evaluation showed that the model was poor $\left(x^{2} / d f=4.511\right.$, GFI $=0.789, \mathrm{NFI}=0.737, \mathrm{CFI}=0.779$, RMSEA $=0.138)$. Some modifications were conducted by deleting some items (INO2.1, INO1.5, PER1 and PER2) and covary e6 with e8. The modification results indicated that the model was fit $\left(x^{2} / d f=2.085\right.$, GFI $=0.915, \mathrm{NFI}=$ 0.0.910, CFI = 0.0.950, RMSEA = 0.077).

Apart from testing the correctness fit of the model, this study also tested the convergent validity, discriminant validity and the uni-dimensionality of the measurements used. The score of the factor loading for each item was above 0.6 with AVE varied between 0.589 and 0.675. These indicators show that there was no convergent validity problem faced by the measures. The discriminant validity problem was evaluated through the correlation among constructs. For this study, the correlation among constructs was below 0.80 . It means that the measures are free from the discriminant validity problem. Unidimensionality was tested by the score of composite reliability. In this study, the score of composite reliability varied between 0.827 and 0.861 . As these scores are above the cut off value ( $\mathrm{CR}>0.7)$, all constructs were uni-dimensional. Table 3 shows the results of the measurement evaluation.

Table 2: Demography or Respondents

\begin{tabular}{|c|c|c|c|}
\hline Variable & & Frequency & $\%$ \\
\hline \multirow[t]{2}{*}{ Gender } & Male & 110 & $59 \%$ \\
\hline & Female & 76 & $41 \%$ \\
\hline \multirow[t]{5}{*}{ Age } & $18-25$ years old & 12 & $6 \%$ \\
\hline & 26-35 years old & 23 & $12 \%$ \\
\hline & $36-45$ years old & 48 & $26 \%$ \\
\hline & 46-55 years old & 67 & $36 \%$ \\
\hline & 55 years old & 36 & $19 \%$ \\
\hline \multirow[t]{5}{*}{ Education } & High school & 58 & $31 \%$ \\
\hline & Diploma & 88 & $47 \%$ \\
\hline & Bachelor & 19 & $10 \%$ \\
\hline & Master & 21 & $11 \%$ \\
\hline & Doctorate & 0 & $0 \%$ \\
\hline \multirow{5}{*}{$\begin{array}{l}\text { Business } \\
\text { duration }\end{array}$} & $3-5$ years & 79 & $42 \%$ \\
\hline & $6-10$ years & 45 & $24 \%$ \\
\hline & $11-15$ years & 27 & $15 \%$ \\
\hline & $>15$ years & 34 & $18 \%$ \\
\hline & Did not mention & 2 & $1 \%$ \\
\hline
\end{tabular}

Table 3: Measurement Items and Confirmatory Factor Analysis

\begin{tabular}{|c|c|c|c|c|c|c|c|}
\hline Constructs & Items & FL & AVE & CR & El & EXO & EXI \\
\hline \multirow{3}{*}{$\begin{array}{l}\text { Entrepre- } \\
\text { neurial } \\
\text { Intensity }\end{array}$} & I never thought to close / sell my business & 0.702 & \multirow[t]{3}{*}{0.675} & \multirow[t]{3}{*}{0.861} & & & \\
\hline & $\begin{array}{l}\text { I would rather run my own business than work at another } \\
\text { company even with a higher salary. }\end{array}$ & 0.865 & & & & & \\
\hline & $\begin{array}{l}\text { I would rather run my own business than pursue another } \\
\text { promising career. }\end{array}$ & 0.885 & & & & & \\
\hline \multirow[t]{4}{*}{$\begin{array}{l}\text { Exploitative } \\
\text { Innovation }\end{array}$} & $\begin{array}{l}\text { There are always new products and services offered by } \\
\text { companies to the market }\end{array}$ & 0.679 & \multirow[t]{4}{*}{0.589} & \multirow[t]{4}{*}{0.851} & \multirow[t]{4}{*}{0.247} & & \\
\hline & $\begin{array}{l}\text { The company transforms new ideas from the market into the next } \\
\text { product line }\end{array}$ & 0.779 & & & & & \\
\hline & $\begin{array}{l}\text { The company is able to innovate new products that have never } \\
\text { been on the market. }\end{array}$ & 0.836 & & & & & \\
\hline & The company is adding new elements to the current product range & 0.685 & & & & & \\
\hline \multirow{2}{*}{$\begin{array}{l}\text { Explorative } \\
\text { Innovation }\end{array}$} & We always improve the efficiency of our products and services & 0.855 & \multirow[t]{2}{*}{0.654} & \multirow[t]{2}{*}{0.847} & \multirow[t]{2}{*}{0.460} & \multirow[t]{2}{*}{0.527} & \\
\hline & Our company expands services for existing clients & 0.916 & & & & & \\
\hline \multirow[t]{3}{*}{$\begin{array}{l}\text { Business } \\
\text { Performance }\end{array}$} & $\begin{array}{l}\text { The company has succeeded in improving the quality of products } \\
\text { and services }\end{array}$ & 0.871 & \multirow[t]{3}{*}{0.617} & \multirow[t]{3}{*}{0.827} & \multirow[t]{3}{*}{0.549} & \multirow[t]{3}{*}{0.520} & \multirow[t]{3}{*}{0.695} \\
\hline & The company has succeeded in increasing employee satisfaction & 0.688 & & & & & \\
\hline & The company has succeeded in increasing customer satisfaction & 0.766 & & & & & \\
\hline
\end{tabular}




\subsection{Hypothesis Test}

As the CFA results showed that the model is fit, the hypotheses tests might be performed. For this study, three hypotheses are proposed. The first hypothesis proposed the positive direct effect of entrepreneurial intensity on business performance. The statistical estimation found that entrepreneurial intensity has a significant positive effect on business performance $(\beta=0.289 ; \mathrm{t}=3.758)$. It supports the Hypothesis 1 . The mediating effect of exploratory innovation in the relationship between entrepreneurial intensity and business performance was proposed by Hypothesis 2. The result of mediation analysis and Sobel's test indicated that exploratory innovation mediates the effect of entrepreneurial intensity on business performance $((\beta=0.060 ; t=2.333)$, which supports Hypothesis 2. Similar to exploratory innovation, this study revealed that the mediation role of exploitative innovation in the relationship between entrepreneurial intensity and business performance $(\beta=$ $0.210 ; \mathrm{t}=3.712$ ). This supports the Hypothesis 3 . Table 4 shows the results of the Hypotheses test.

\section{Discussion and Conclusion}

Based on the proposed research objectives, the study aims to determine the effect of entrepreneurial intensity on SME's business performance in the area of Indonesian manufacturing sector. In addition, this study investigates the mediating effect of both exploitative and exploratory innovation in the relationship between entrepreneurial intensity on business performance. Figure 2 shows the tested structural model.

Table 4: Hypothesis Test

\begin{tabular}{|l|l|c|c|c|}
\hline Hypothesis & Path & Coefficient & t-statistic & Remarks \\
\hline $\mathrm{H} 1$ & $\mathrm{EI} \rightarrow \mathrm{BP}$ & 0.289 & 3.758 & Supported \\
\hline $\mathrm{H} 2$ & $\mathrm{El} \rightarrow \mathrm{EXO} \rightarrow \mathrm{BP}$ & 0.060 & 2.333 & Supported \\
\hline $\mathrm{H} 3$ & $\mathrm{EI} \rightarrow \mathrm{EXI} \rightarrow \mathrm{BP}$ & 0.210 & 3.712 & Supported \\
\hline
\end{tabular}

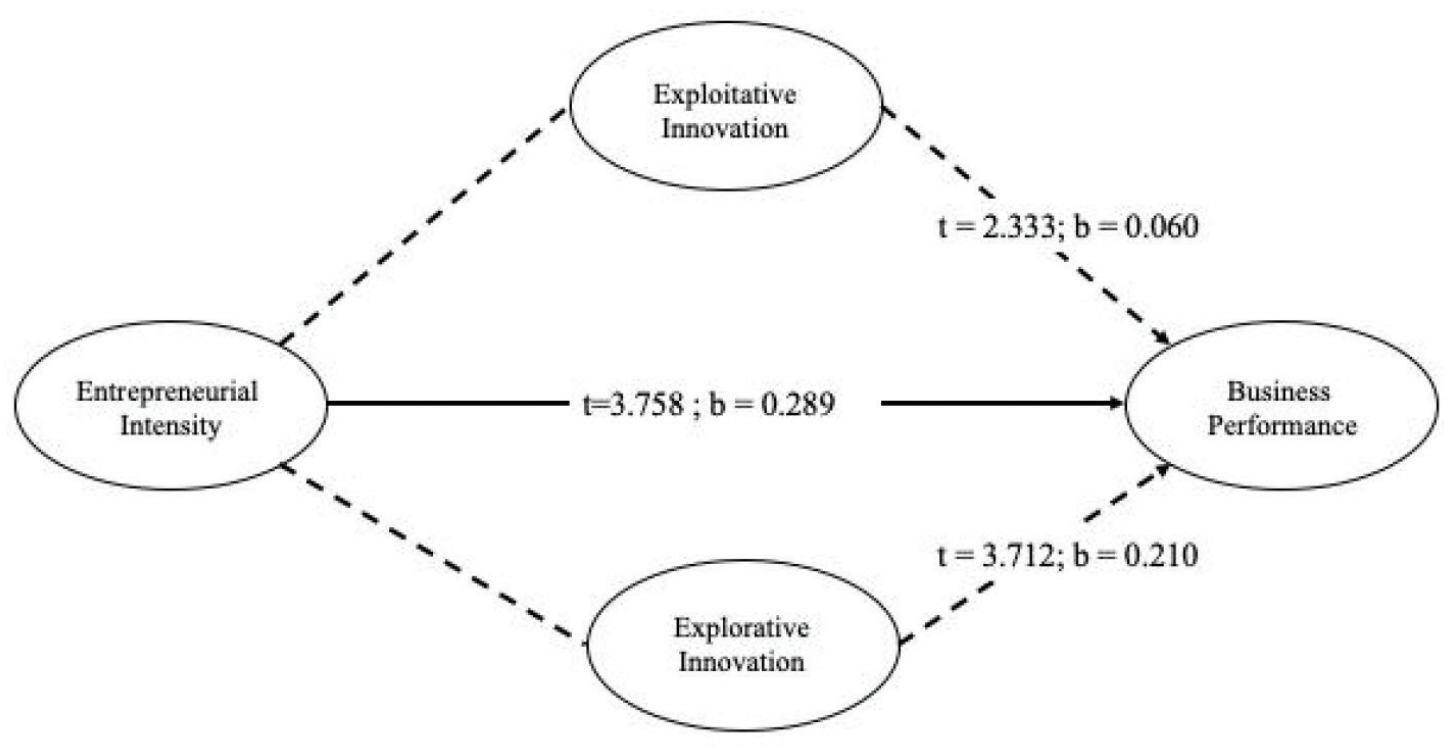

Figure 2: Structural Model 
In the middle of business competition, every single business organization needs to have high business performance. Resource - Advantage (R-A) Theory suggests that having comparative advantage will help the business organizations to have high business performance. Using R-A Theory as the foundation, this study proposed the role of entrepreneurial intensity as the determinant of business performance. In this study, entrepreneurial intensity coming from the inside the organization is predicted as an important resource in enhancing business performance. Hypothesis test shows that entrepreneurial intensity plays an important role in having an effect on business performance. This finding theoretically implies that the higher the degree and frequency of entrepreneurship owned by the owner of a small business is, the better the business performance will be.

The degree of entrepreneurial intensity in this research is reflected by three items: first, the owners of the SMEs never thought to close / sell their business; second, the owners of the SMEs would rather to run their own business than work at another company even with a higher salary; and third, the owners of the SMEs should rather run their own business rather than pursuing another promising career. It strengthens the previous studies such as by Lakovleva and Kickul (2011) and Morris and Sexton (1996), who found the same results. Practically, this study contends that every business person needs to have high entrepreneurial intensity. This intensity can be enhanced by several factors such as education and new insights from peer group of entrepreneurs. These factors are important for individuals to enhance their intensity since these factors strengthen the motivation level of the entrepreneurs. By successfully increasing the entrepreneurial intensity, there is a big chance for business owners to have higher business performance. SME performance in this research is reflected by improved quality of goods and services and increased employee and customer satisfaction.

Apart from the direct relationship between entrepreneurial intensity and business performance, this study investigated the mediation role of innovation. Specifically, this study tested the mediation role of both exploratory and exploitative innovation in the relationship between entrepreneurial intensity and business performance. Exploitative innovation is captured by creating new products, implementing new ideas, and adding new elements to the current product range. While explorative innovation is reflected by the efficiency improvement of product and services provided by the SMEs, and expanding services for the existing customers. The findings of this study explained that both exploratory and exploitative innovation mediated the effect of entrepreneurial intensity on business performance. Theoretically, this results validated R-A Theory (Hunt \& Morgan, 1996) by explaining that resources owned by the organization will create a competitive advantage, which will improve the business performance. In other words, the intensity of entrepreneurship of small business owners will have an effect on the small business performance directly and innovations will ultimately increase the performance of their firms. The entrepreneurial intensity owned by business organizations is an important resource to create competitive advantage which results in enhanced business performance. While previous studies did not specify the types of innovation needed for a firm's competitive advantage, this study suggested that both exploitative innovation and exploratory innovation will generate the business performance. Practically, it implies that SME practitioners should be able to exploit the resources from inside the organization and explore the environment in order to be innovative.

Upon its completion, this study provides both theoretical and practical solutions to enhance business performance of small firms. As far as theoretical contribution is concerned, this study provides a conceptual model which explains the relationship between entrepreneurial intensity, exploratory innovation, exploitative innovation, and small business performance in the context of small manufacturing business sector of Indonesia. Apart from this, the study shows the importance of both exploratory and exploitative innovation as a mediating variable in the relationship between entrepreneurial intensity and business performance. For practical contribution, this study provides insights for small business practitioners to improve innovation and business performance. In order to enhance innovation activities and business performance, small and medium business owners should know that their entrepreneurial intensity is one of the essential factors. Practically, this study helps SME practitioners and educators to enhance SMEs performance in the area of small business manufacturing sector in Indonesia.

\section{Limitation and Future Study}

While this study provides both theoretical and practical contributions, this study also has some limitations. The first limitation is the convenience sampling method used to collect the samples. As the sample was collected by using convenience sampling, the results of this study cannot be easily generalized to other industries or locations. Second, this study only focusses on innovation and entrepreneurial intensity in predicting Indonesian small business performance in the area of the manufacturing industry. To have a better understanding of small business performance, the next study might add variables such as learning orientation, entrepreneurial market orientation, and marketing capabilities. 


\section{References}

Bakar, L. J. A., \& Ahmad, H. (2010). Assessing the relationship between firm resources and product innovation performance: a resource-based view. Business Process Management Journal, 16(3), 420-435.

Hair, J. F., Anderson, R. E., \& Tatham, R. (2010). Multivariate Data Analysis With Readings. Englewood Cliffs, NJ: Prentice Hall.

Hoang, C. C., \& Ngoc, B. H. (2019). The relationship between innovation capability and firm's performance in electronic companies, Vietnam. Journal of Asian Finance, Economics and Business, 6(3), 295-304. https://doi.org/doi:10.13106/ jafeb.2019.vol6.no3.295

Hogan, S. J., \& Coote, L. V. (2014). Organizational culture, innovation, and performance: A test of Schein's model. Journal of Business Research, 67(8), 1609-1621.

Hunt, S. D, \& Morgan, R. M. (2005). The Resource-Advantage Theory of Competition. In: N. K. Malhotra (Eds.), Review of Marketing Research (Vol. 1, pp. 153-206). Emerald Group Publishing Limited. https://doi.org/10.1108/S1548-6435 (2004) 0000001008

Hunt, S. D., \& Morgan, R. M. (1996). The Resource-Advantage Theory of Competition: Dynamics, Path Dependencies, and Evolutionary Dimensions. Journal of Marketing, 60(4), 107114. https://doi.org/10.2307/1251905

Jansen, J. J. P., Van den Bosch, F. A. J., \& Volberda, H. W. (2005). Exploratory Innovation, Exploitative Innovation, and Ambidexterity: The Impact of Environmental and Organizational Antecedents. Schmalenbach Business Review, 57(4), 351-363.

Jansen, J. J. P., Van Den Bosch, F. A. J., \& Volberda, H. W. (2006). Exploratory Innovation, Exploitative Innovation, and Performance: Effects of Organizational Antecedents and Environmental Moderators. Management Science, 52(11), 1661-1674. https://doi.org/10.1287/mnsc.1060.0576

Jianwen, L. (2005). Developing and validating a construct of entrepreneurial intensity. New England Journal of Entrepreneurship, 8(2), 31-38. https://doi.org/10.1108/NEJE08-02-2005-B004

Lakovleva, T., \& Kickul, J. (2011). Beyond social capital: The role of perceived legitimacy and entrepreneurial intensity in achieving funding success and superior venture performance in women-led Russian SMEs. International Journal of Entrepreneurship and Small Business, 14(1). https://doi. org/10.1504/IJESB.2011.042161

Lee, Y.-K., Kim, S.-H., Seo, M.-K., \& Hight, S. K. (2015). Market orientation and business performance: Evidence from franchising industry. International Journal of Hospitality Management, 44, 28-37

Lestari, S. D., Leon, F. M., Widyastuti, S., Brabo, N. A., \& Putra, A. H. P. K. (2020). Antecedents and consequences of innovation and business strategy on performance and competitive advantage of SMEs. Journal of Asian Finance, Economics and Business, 7(6), 365-378. https://doi.org/doi:10.13106/ jafeb.2020.vol7.no6.365

Li, Y., Zhou, N., \& Si, Y. (2010). Exploratory innovation, exploitative innovation, and performance: Influence of business strategies and environment. Nankai Business Review International, 1(3), 297-316

Medina, C., \& Rufín, R. (2009). The mediating effect of innovation in the relationship between retailers' strategic orientations and performance. International Journal of Retail \& Distribution Management, 37(7), 629-655.

Morris, M.H., \& Sexton, D. L. (1996). The concept of entrepreneurial intensity: Implications for company performance. Journal of Business Research, 36(1), 5-13. https://doi.org/https://doi. org/10.1016/0148-2963(95)00158-1

Mueller, V., Rosenbusch, N., \& Bausch, A. (2013). Success Patterns of Exploratory and Exploitative Innovation: A Meta-Analysis of the Influence of Institutional Factors. Journal of Management, 39(6), 1606-1636. https://doi.org/10.1177/0149206313 484516

Murat A. I., \& Baki, B. (2011). Antecedents and performance impacts of product versus process innovation: Empirical evidence from SMEs located in Turkish science and technology parks. European Journal of Innovation Management, 14(2), 172-206.

Nguyen, T. T., Pham, N. T., Dao, V. P. L., Ngo, T. T. T., \& Le, T. T. B. (2020). Critical Factors Affecting the Innovation Activities of Businesses: Evidence from Binh Dinh Province, Vietnam. Journal of Asian Finance, Economics and Business, 7(7), 425438 .

Urban, B., \& Sefalafala, M. R. (2015). The influence of entrepreneurial intensity and capabilities on internationalisation and firm performance. South African Journal of Economic and Management Sciences, 18(2), 260-276.

Wiklund, J., \& Shepherd, D. (2005). Entrepreneurial orientation and small business performance: a configurational approach. Journal of Business Venturing, 20(1), 71-91. https://doi.org/ https://doi.org/10.1016/j.jbusvent.2004.01.001

Zhang, J., \& Duan, Y. (2010). The impact of different types of market orientation on product innovation performance: Evidence from Chinese manufacturers. Management Decision, $48(6), 849-867$. 